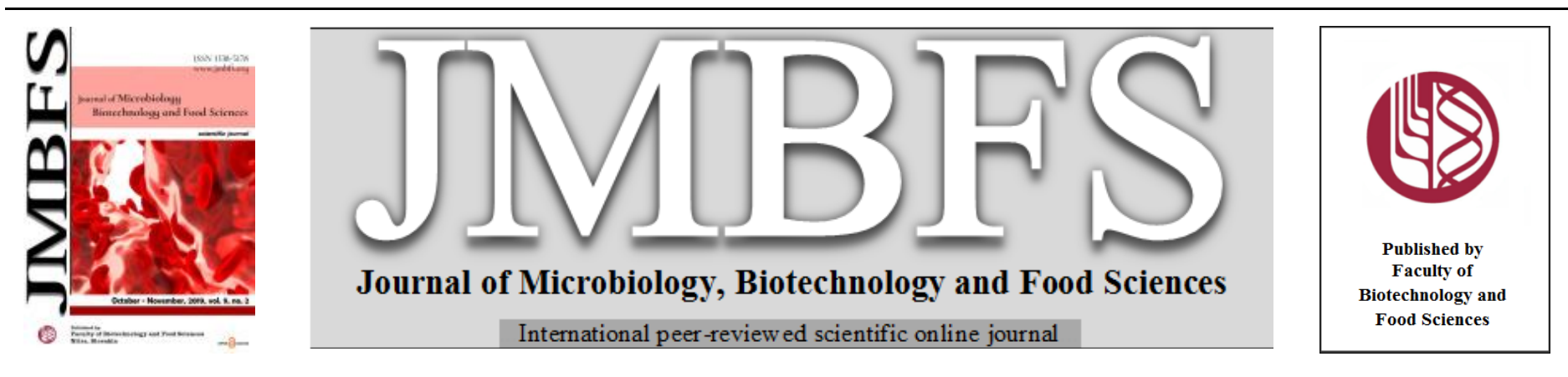

\title{
CLONING, EXPRESSION AND T CELL EPITOPE PREDICTION OF FBPA AND FBPB GENES OF MYCOBACTERIUM TUBERCULOSIS CLINICAL ISOLATES
}

\section{Fihiruddin ${ }^{1,2}$, Wayan Tunas Artama ${ }^{3,4}$, Tri Wibawa ${ }^{5}$, Ni Made Mertaniasih ${ }^{6}$}

Address(es): Prof. Dr. drh.Wayan Tunas Artama'

${ }^{1}$ Doctoral Program, Research Center of Biotechnology, Universitas Gadjah Mada, Barek, Jl. Teknika Utara Street, Kocoran, Caturtunggal, Sleman, 55281 Yogyakarta. Indonesia. Phone: +62-0274-6492284.

${ }^{2}$ Department of Medical Laboratory Technology, Politeknik Kesehatan Mataram, Praburangkasari Street, Indonesia.

${ }^{3}$ Department of Biochemistry, Faculty of Veterinary Medicine, Universitas Gadjah Mada, Fauna Street No. 2, Caturtunggal, Sleman, Yogyakarta 55281,Yogyakarta. Indonesia. Phone:+62-0274-6492088, 560862.

${ }^{4}$ One Health/Ecohealth Resource Center, Universitas Gadjah Mada, Yogyakarta. Indonesia.

${ }^{5}$ Department of Microbiology, Faculty of Medicine, Public Health and Nursing, Universitas Gadjah Mada. Farmako street, Senolowo, Sekip Utara, Yogyakarta Indonesia; Phone: +62-0274- 560300.

${ }^{6}$ Department of Clinical Microbiology, Faculty of Medecine, Universitas Airlangga. Street Mayjen. Prof. Dr. Moestopo 47, Surabaya Indonesia.

*Corresponding author: artama@ugm.ac.id

doi: $10.15414 /$ jmbfs.2020.9.5.998-1002

\section{ARTICLE INFO}

Received 15.11.2019

Revised 6. 12. 2019

Accepted 10. 12. 2019

Published 1. 4. 2020

Regular article

open ${ }_{\text {ACCESS }}$

\begin{abstract}
The effective treatment and accurate diagnosis of tuberculosis (TB) are not established yet. The Bacillus Chalmette-Guerin vaccine did not provide significant results in the prevention of TB and had only 0-80\% efficacy. The $f b p A$ and $f b p B$ genes of $M$. tuberculosis are antigenic proteins and considered to be virulence factors. They are capable of stimulating immune responses in TB patients. In this study, we observed cloning, expression and T-cell epitope prediction of $f b p A$ and $f b p B$ genes from clinical isolates. The isolates of MultiDrug-Resistant (MDR-TB) were cultured and extracted. The fresh Polymerase Chain Reaction (PCR) products of the fbpA and $f b p B$ genes were inserted into pET SUMO plasmids and transformed into Escherichia coli BL21 (DE3), then expressed in LB medium induced by $1.0 \mu \mathrm{M}$ of IPTG. Sample sequences were analyzed by ClustalW and NCBI BLAST programs. The T-cell epitope prediction was analyzed by GENETYX vers 8.0. The PCR results were $1071 \mathrm{bp}$ ( $f b p A$ gene) and $978 \mathrm{bp}$ ( $f b p B$ gene). The SDS-PAGE and Western blotting weighed $48-\mathrm{kDa}$ ( $f b p A$ gene) and 46-kDa ( $f b p B$ gene). We obtained seven specific T-cell epitopes based on IAd Pattern Position on both genes. Based on Rothbard/Taylor Pattern Position, we discovered twenty-three and sixteen specific T-cell epitopes for $f b p A$ and $f b p B$ genes, respectively. The $f b p A$ and $f b p B$ genes that encode Ag85A and Ag85B proteins have epitopes that are recognized by lymphocyte T-cells and are potentially subunit TB vaccine candidates in the future.
\end{abstract}

\section{INTRODUCTION}

Tuberculosis (TB) is an infectious disease that causes high rates of mortality and morbidity worldwide, especially in developing countries and continues to be a challenging burden on public health. Globally, there were 6.3 million new cases of TB in 2017 and the mortality rate reached 1.3 million, making TB the second leading cause of death from infectious diseases after Human Immunodeficiency Virus (HIV) Infection. Indonesia has the second largest burden of TB cases in the world after India. In 2017, there were 425,089 TB cases in Indonesia, indicating a dramatic increase compared to the previous year of 360,565 cases with a mortality rate of 42 per 100,000 population (Wang et al., 2017; WHO 2018; Ministry of Indonesia Health 2018). The problem of preventing and controlling TB is very complex because the effective TB treatment and accurate diagnosis are not established yet (Guginno et al., 2015). Mycobacterium tuberculosis has unique characteristics, such as slow bacterial growth, diverse strains, and virulence due to multidrug-resistant tuberculosis (MDR-TB), which increases human susceptibility to HIV, and manifests latent infections that reach $40-50 \%$ of cases. Meanwhile, there are decreasing effectiveness of TB vaccines and less optimal diagnostic methods (WHO 2014; Yuen et al., 2014). To date, TB treatment and prevention protocols still apply the Directly Observed Treatment Short-Course (DOTS) program and the administration of the Bacilli CulmetteGuerin (BCG) vaccine. Unfortunately, both the DOTS program and BCG vaccine are not proceeding optimally. The conventional $\mathrm{BCG}$ vaccine is still the major vaccine in early protection against $M$. tuberculosis infection. It cannot provide optimal protection to prevent the transmission of MDR-TB and the current epidemic of TB cases. The BCG vaccine is only effective in preventing miliary $\mathrm{TB}$ or meningitis prevention for children, but does not provide protection in pulmonary TB for adults with latent and reactivation of TB (Piubelli et al., 2013). The development of better diagnostic tools and the discovery of new vaccine candidates are the two main ways to solve the TB problems (Dillon et al., 2000; WHO 2013). Ag85 complex is a main fraction of the excretory protein of M. tuberculosis and M. bovis BCG culture filtrate that has the potential to increase protection against TB. This protein is present on the cell wall surface and needed for the survival of M. tuberculosis in macrophages (Kuo et al., 2013) Antigen 85 complex (Ag85A, Ag85B, Ag85C) has a mycolyl transferase enzyme activity that is involved in mycolic acid pathway to arabinogalactan from cell walls and required for biogenesis in cord factors (trehalose-dimycolate). These proteins contribute to the attachment of $M$. tuberculosis to host cells and can maintain M. tuberculosis survival in the intracellular parts of host cells. (Launois et al., 2011; Piubelli et al., 2013: Zarif et al., 2013). The proteins of Ag85A and Ag85B are encoded by the $f b p A$ and $f b p B$ genes, respectively. Secreted antigen 85 protein is immunogenic and expressed continuously by $M$. tuberculosis and can stimulate B cell and T cell responses. T cells can activate the cellular and humoral immunity system through release of cytokines and activating macrophage cells, NK cells, DC cells and Tc cells to destroy intracellular $M$. tuberculosis-infected cells (Jiang et al., 2015; Rizzi et al., 2012; Metcalfe et al., 2016). Recombinants of $\mathrm{Ag} 85 \mathrm{~A}$ ( $32 \mathrm{kDa}$ ) and $\mathrm{Ag} 85 \mathrm{~B}$ (30 kDa) proteins are promising for TB vaccine candidates because they are the major proteins secreted by $M$. tuberculosis and show strong immunogenic properties (Yuk et al., 2016). This study aimed to clone, express and predict the specific T cell epitopes of the $f b p A$ and $f b p B$ genes of $M$. tuberculosis from clinical isolates. 


\section{MATERIAL AND METHODS}

\section{Extraction and measurement concentration of DNA}

In this study, isolates of $M$. tuberculosis were obtained from sputum of patients who were diagnosed with MDR-TB in Dr. Sutomo Hospital Surabaya. TB Ag MPT 64 Rapid test (SD Bioline) was used for detection of bacterial antigens in serum. The isolates of $M$. tuberculosis were subcultured (refreshed) to elicit isolates in 2-3 weeks of log phase growth. The DNA of isolates were extracted using the DNeasy Blood and Tissue Kit (Qiagen). Resistance test and DNA extraction of isolates were performed in Balai Besar Labaratorium Kesehatan (BBLK) Surabaya and used M. tuberculosis strain H37Rv as a control. Identification of MDR-TB was done on Lowenstein Jensen (LJ) medium with BACTEC MGIT 960 System (BD) methods and confirmed by GeneXpert $\mathbb{R}$ System (Cepheid USA) test. The concentration of bacterial DNA extract was measured by a NanoDropTM2000/ 2000c Spectrophotometer (Thermo Fisher Scientific, USA).

\section{Design of primers and Polymerase Chain Reaction (PCR)}

The nucleotide sequence of the primers used in this study was determined by the genome sequence of M. tuberculosis H37Rv (ATCC 27294) which was obtained from GenBank and designed by BLAST pick primers software (www.ncbi.nlm.nih.gov/tools/primer-blast/index). The Primary forward used is 5'- GGA TGC GTT GAG ATG AGG ATG AG -3 ', reverse primer: 5'- GTT TCC TAA ATC CCG TCC CTA GCT -3', (fbpA gene) and forward 5'- ACA GAC GTG AGC CGA AAG ATT C -3 'and as a reverse primer are: 5'- TCA GCC GGC $G C C T A A C G A$ ACT $C T-3^{\prime}$ ( $f b p B$ gene). The PCR was performed in a total volume of $25 \mu \mathrm{l}$, that contained $12.5 \mu \mathrm{L}$ PCR mix (GoTaq Green Master Mix

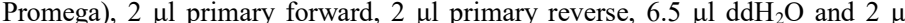
DNA template. An initial denaturation of $5 \mathrm{~min}$ at $95^{\circ} \mathrm{C}$ was followed by 35 cycles of denaturation at $95^{\circ} \mathrm{C}$ for $5 \mathrm{~s}$, annealing at $56^{\circ} \mathrm{C}$ for $1 \mathrm{~s}$, and extension at $72^{\circ} \mathrm{C}$ for $1 \mathrm{~min}$, followed by a final extension at $72^{\circ} \mathrm{C}$ for $10 \mathrm{~min}$, then the tube was cooled for 10 minutes at $12^{\circ} \mathrm{C}$. The PCR product was analyzed by electrophoresis on $1 \%$ agarose gel in Tris/boric acid/EDTA buffer and observations were conducted in transilluminator UV light.

\section{Cloning, transformation and expression of Ag85 proteins}

The fresh PCR product was mixed with $\mathrm{pET}$ SUMO plasmid (Champion ${ }^{\mathrm{TM}} \mathrm{pET}$ SUMO Protein Expression System, Invitrogen) for ligation process by T4 DNA ligase in a microtube. Then, it was incubated at $15^{\circ} \mathrm{C}$ for at least 4 hours or $\left(15^{\circ} \mathrm{C} /\right.$ overnight $)$ in a water bath and transformed into $E$. coli competent cells (One Short ${ }$ Mach1TM-T1R) with heat shocked method at $42^{\circ} \mathrm{C}$ for 30 seconds The results of transformation were then spread on LB medium containing 50 $\mu \mathrm{g} / \mathrm{ml} \mathrm{kanamycin}$ and incubated at $37^{\circ} \mathrm{C}$ for 24 to $48 \mathrm{~h}$. The plasmids were purified using a commercial kit (PureLinkTM HQ Mini Plasmid Purification Kit) and transformed into E. coli BL21(DE3) competent cells (One Short ${ }^{\circledR}$ cells). The transformed bacteria were grown in $5 \mathrm{ml}$ Luria-Bertani (LB) broth medium containing $50 \mu \mathrm{g} / \mathrm{ml}$ kanamycin, and incubated at $37^{\circ} \mathrm{C} 180 \mathrm{rpm}$ for overnight. Then, $5 \%$ of overnight culture was removed to $100 \mathrm{~mL} \mathrm{LB}$ broth medium, incubated with shaking at $37^{\circ} \mathrm{C}$ for $4 \mathrm{~h}$ (optical density \pm 0.6 ), and supplemented with $1 \mathrm{mM}$ IPTG (Amresco, USA). The incubation was continued for $3 \mathrm{~h}$, then the cell pellet was collected by centrifugation at $4^{0} \mathrm{C}, 10,000 \mathrm{rpm}$ for $5 \mathrm{~min}$. The bacterial cells were then re-suspended three time in Phosphate Buffer Saline (PBS) and degraded by sonicator. The supernatants were collected by centrifugation at $4^{0} \mathrm{C}, 10,000 \mathrm{rpm}$ for $5 \mathrm{~min}$.

\section{Purification and SDS-PAGE}

The Ag85A and Ag85B recombinant proteins were purified using nickel column chromatography and the purified lysate was loaded into a $10 \mathrm{ml} \mathrm{Ni-NTA} \mathrm{column}$ (Ni-NTA Purification System, NOVEX by Lab Technologies Cat No. K950-01) Initially, the column was washed with wash buffer $\left(250 \mathrm{mMNaH}_{2} \mathrm{PO}_{4}, 2.5 \mathrm{M}\right.$ $\mathrm{NaCl}$ and $100 \mu \mathrm{L} 3 \mathrm{M}$ imidazole). The proteins were eluted with elution buffer (250 $\mathrm{mMNaH}_{2} \mathrm{PO}_{4}, 2.5 \mathrm{M} \mathrm{NaCl}$ and $1.25 \mathrm{~mL} 3 \mathrm{M}$ imidazole). The purified recombinant proteins and supernatant of cell pellets were analyzed using $15 \%$ sodium dodecyl sulfate-polyacrylamide gels. The protein samples were taken and then added with loading dye with a ratio of $1: 4(10 \mu \mathrm{l}$ loading dye: $40 \mu \mathrm{l}$ sample), then heated at $80^{\circ} \mathrm{C}$ for $5 \mathrm{~min}$. Electrophoresis was performed at 120 volts for 2 hours. The proteins were visualized by staining with Coomassie blue for 1 hour using a shaker. The gel was washed with aquabidest, then washed with a solution of destining (50\% methanol, $10 \%$ acetic acid glacial, and $40 \%$ aquabidest) for $30 \mathrm{~min}$ until the band was clearly visible.

\section{Western blotting of recombinant proteins of Ag85A and Ag85B}

The protein bands from the SDS-PAGE were transferred to polyvinylidene fluoride paper (PVDF) using Bio-Rad's semi-dry blotter tool with an electric current of $500 \mathrm{~mA}$ for $120 \mathrm{~min}$. In the next step the PVDF paper was blocked by
Bovine serum albumin 1\%, then anti-histidine Tag monoclonal antibody and secondary antibody (Goat IgG anti-mouse) were added. After the washing process, this reaction was ended by the adding of NBT/BCIP substrate for 2-5 minutes.

\section{T cell epitope prediction of recombinant proteins of Ag85A and Ag85B}

PCR products of the $f b p A$ and $f b p B$ genes were sent to 1st BASE for sequencing processes. 1st BASE used ABI PRISM 370xl Genetic Analyzer (Applied Biosystem). Sample sequences were then analyzed using ClustalW (www.genome.jp/tools-bin/clustalw). The $\mathrm{T}$ cell epitopes' prediction was analyzed by GENETYX version 8.0 .

\section{RESULTS}

Amplification of the $f b p A$ and $f b p B$ genes of $M$. tuberculosis which encode the $\mathrm{Ag} 85 \mathrm{~A}$ and $\mathrm{Ag} 85 \mathrm{~B}$ proteins was found to be of $1071 \mathrm{bp}$ and $978 \mathrm{bp}$, respectively (Figure 1). In this study, we used twenty-five (25) MDR-TB clinical isolates, with all samples showing the properly positioned band of the $f b p A$ and $f b p B$ genes. The alignment of the sequencing of those genes was analyzed by the ClustalW program which was compared to the original sequence of $M$ tuberculosis $H 37 R v$. The alignment results showed a high similarity of sample sequences with $M$. tuberculosis $\mathrm{H} 37 \mathrm{Rv}$ which was $99 \%$. We also analyzed the sample sequences using the NCBI BLAST program and showed that all sample sequences had a $100 \%$ homologous sequence with various strains of $M$ tuberculosis found in the NCBI data base (Table 1). The fresh PCR product from the amplified $f b p A$ and $f b p B$ genes which have the similar sequence with $M$. tuberculosis $\mathrm{H} 37 \mathrm{Rv}$ were then inserted into the pET SUMO plasmids and transformed to $E$. coli competent cells. The E. coli bacteria carrying plasmids were grown in LB agar medium, otherwise those that do not contain plasmids cannot grow. The growth of each $E$. coli bacteria that were carrying different plasmids in the medium showed different numbers of colonies. The colonies of $E$ coli competent cells carrying the inserted $f b p A$ and $f b p B$ genes that grew on the LB agar medium were 5 and 18 colonies, respectively (Figure 2).

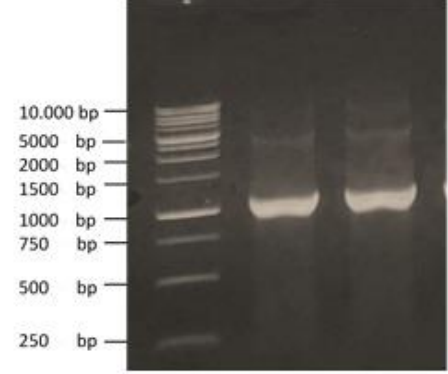

123

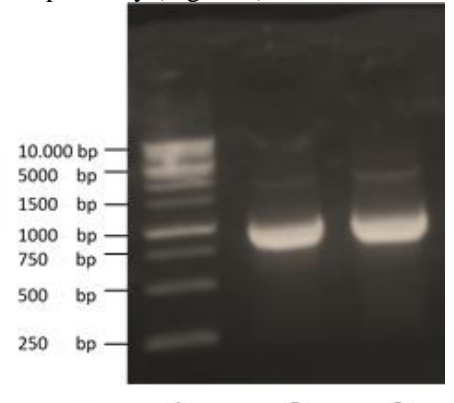

4

56
Figure 1 Results of PCR samples of clinical isolate. Line 1: DNA ladder, line 2 and 3: $f b p A$ gene (1071bp), line 4: DNA ladder, line 5 and 6: $f b p B$ gene (978 bp).
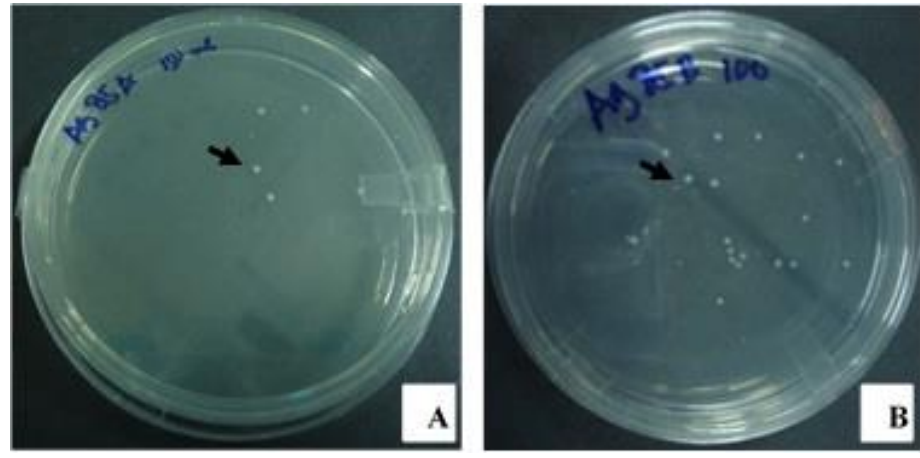

Figure 2 The growing of $E$. coli competent cells on LB agar. The colonies of $E$. coli competent cells containing a pET SUMO plasmid inserted with $f b p A$ gene (A) and $f b p B$ gene (B) of $M$. tuberculosis.

Sodium dodecyl sulfate polyacrylamide gel electrophoresis (SDS-PAGE) of the purified Ag85A and $\mathrm{Ag} 85 \mathrm{~B}$ recombinant proteins in Figure 3 showed that the molecular weights were $48 \mathrm{kDa}$ and $46 \mathrm{kDa}$, respectively. The Western blotting examinations of recombinant proteins performed with PVDF paper elicited the similar molecular weights of Ag85A and Ag85B proteins with SDS-PAGE of 48 $\mathrm{kDa}$ and $46 \mathrm{kDa}$, respectively. The results of SDS-PAGE and Western blotting recombinant protein product using anti-histidine taq monoclonal antibody $(6 \mathrm{x})$ are shown in Figures 3 and 4. 

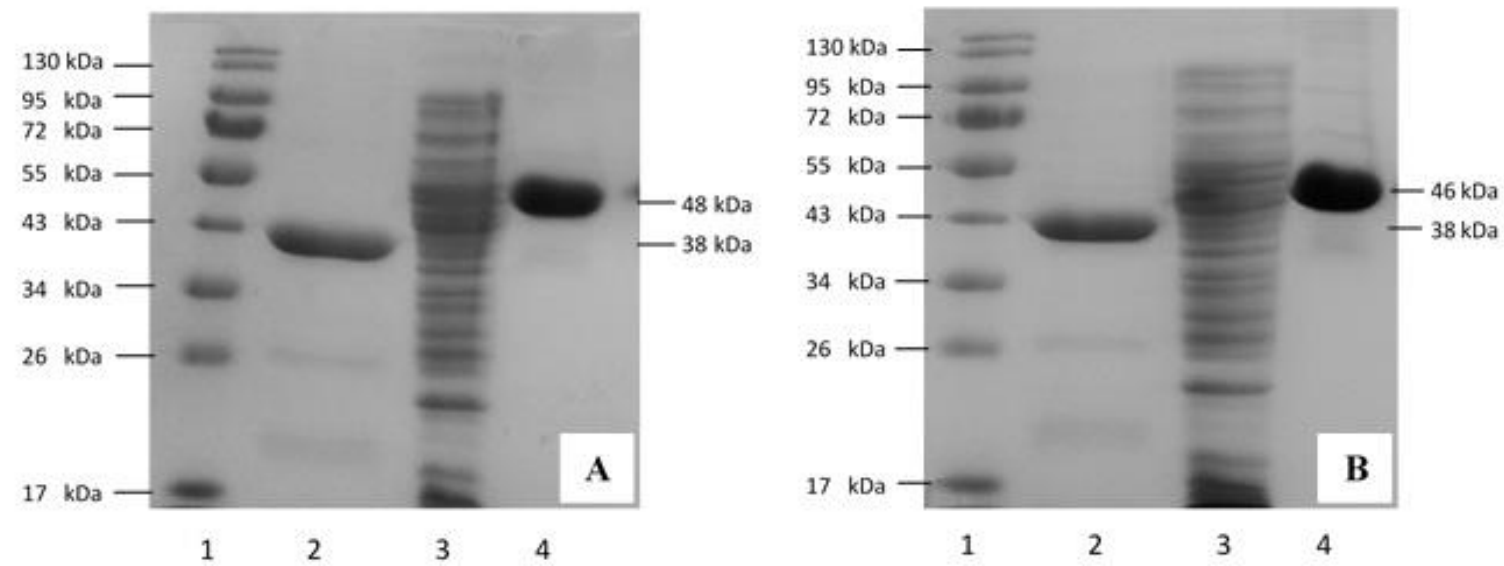

Figure 3 SDS-PAGE of purified Ag85A and Ag85B proteins pET SUMO clone in E. coli BL21 (DE3). Line 1: protein ladder, line 2: positive control (38-kDa), line 3: negative control (E. coli BL21 without pET SUMO plasmid), line 4: a purified Ag85A proteins (A). Line 1: protein ladder, line 2: positive control, line 3: negative control (E. coli BL21 without pET SUMO plasmid), and line 4: a purified Ag85B protein (B).

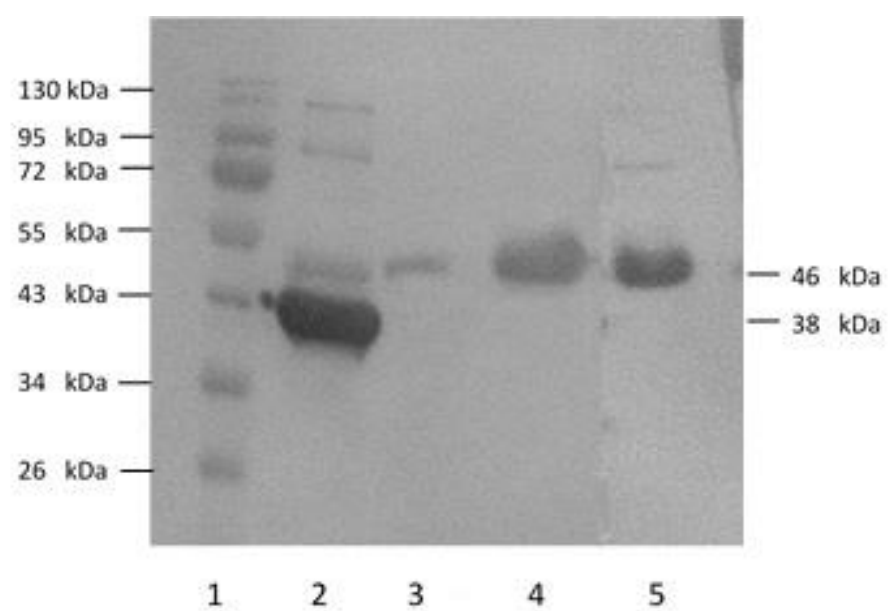

Figure 4 Western blotting of $\mathrm{Ag} 85 \mathrm{~A}$ and $\mathrm{Ag} 85 \mathrm{~B}$ proteins by using $6 \mathrm{x}$ antihistidine Tag monoclonal antibody. line 1: protein ladder, line 2: positive control (38-kDa), line 3 and 4: a purified $\mathrm{Ag} 85 \mathrm{~A}$ protein $(48 \mathrm{kDa})$, and line 5: a purified $\mathrm{Ag} 85 \mathrm{~B}$ protein $(46 \mathrm{kDa})$.

The $f b p A$ and $f b p B$ genes of $M$. tuberculosis each had seven specific epitopic T cells prediction based on the IAd Pattern Position, while the prediction of specific $\mathrm{T}$ cell epitopes based on the Rothbard/Taylor Pattern Position shows that the $f b p A$ gene has 23 specific $\mathrm{T}$ cell epitopes and $f b p B$ gene has 16 specific $\mathrm{T}$ cell epitope positions (Table 2).

Table 1 Homology of samples isolate with bacteria in NCBI database.

\begin{tabular}{|c|c|c|c|c|}
\hline No & Bacteria species & $\begin{array}{c}\text { Query } \\
(\%)\end{array}$ & $\begin{array}{c}\text { Coverage } \\
\text { E.value }\end{array}$ & $\begin{array}{c}\text { Identity } \\
(\%)\end{array}$ \\
\hline 1. & M. tuberculosis strain DKC2 & 100 & 0.0 & 100 \\
\hline \multirow[t]{2}{*}{2.} & M. tuberculosis variant bovis & 100 & 0.0 & 100 \\
\hline & BCG strain BCG-S48 & 100 & 0.0 & 100 \\
\hline \multirow{2}{*}{$\begin{array}{l}3 . \\
4 .\end{array}$} & tuberculosis & 100 & 0.0 & 100 \\
\hline & TBMENG-03 & 100 & 0.0 & 100 \\
\hline & M. tuberculosis strain H107 & 100 & 0.0 & 100 \\
\hline & M. tuberculosis strain $\mathrm{H} 83$ & 100 & 0.0 & 100 \\
\hline \multirow{2}{*}{$\begin{array}{l}7 . \\
8 .\end{array}$} & M. tuberculosis strain GG- & 100 & 0.0 & 100 \\
\hline & $229-10$ & 100 & 0.0 & 100 \\
\hline \multirow{5}{*}{$\begin{array}{l}9 . \\
10 .\end{array}$} & M. tuberculosis strain GG- & 100 & 0.0 & 100 \\
\hline & $186-10$ & 100 & 0.0 & 100 \\
\hline & $\begin{array}{l}\text { M. tuberculosis strain GG- } \\
137-10\end{array}$ & & & \\
\hline & $\begin{array}{l}\text { M. tuberculosis strain GG- } \\
134-11\end{array}$ & & & \\
\hline & $\begin{array}{l}\text { M. tuberculosis strain GG- } \\
129-11\end{array}$ & & & \\
\hline
\end{tabular}

Table 2 Prediction of $\mathrm{T}$ cell epitopes of $\mathrm{Ag} 85 \mathrm{~A}$ and $\mathrm{Ag} 85 \mathrm{~B}$ recombinant proteins of M. tuberculosis.

\begin{tabular}{|c|c|c|c|c|}
\hline \multirow{3}{*}{ Gene } & \multicolumn{4}{|c|}{ T cell epitope } \\
\hline & \multicolumn{2}{|c|}{ IAd Pattern Position } & \multicolumn{2}{|c|}{$\begin{array}{c}\text { Rothbard/Taylor Pattern } \\
\text { Position }\end{array}$} \\
\hline & $\begin{array}{l}\text { Amino } \\
\text { acid } \\
\text { position }\end{array}$ & Sequence & $\begin{array}{l}\text { Amino acid } \\
\text { position }\end{array}$ & Sequence \\
\hline$f b p A$ & $\begin{array}{c}18-23 \\
39-44 \\
46-51 \\
93-98 \\
179-184 \\
183-188 \\
225-230\end{array}$ & $\begin{array}{c}\text { VRGAVT } \\
\text { VSGLVG } \\
\text { VGGTAT } \\
\text { LDGLRA } \\
\text { LSMETA } \\
\text { ASSALT } \\
\text { AGGYKA }\end{array}$ & $\begin{array}{c}20-23 \\
28-32 \\
32-35 \\
41-44 \\
44-47 \\
53-56 \\
59-63 \\
158-161 \\
161-164 \\
201-204 \\
205-208 \\
219-223 \\
232-235 \\
239-243 \\
253-257 \\
260-264 \\
253-257 \\
281-284 \\
285-288 \\
306-309 \\
309-312 \\
334-337 \\
343-347\end{array}$ & $\begin{array}{c}\text { GAVT } \\
\text { RLVVG } \\
\text { GAVG } \\
\text { GLVG } \\
\text { GAVG } \\
\text { GAFS } \\
\text { GLPVE } \\
\text { ELPG } \\
\text { GWLQ } \\
\text { GAMS } \\
\text { GLLD } \\
\text { GLAMG } \\
\text { DMWG } \\
\text { DPAWQ } \\
\text { DPLLN } \\
\text { KLIAN } \\
\text { RVWVY } \\
\text { KFLE } \\
\text { GFVR } \\
\text { GVFD } \\
\text { DFPD } \\
\text { RALG } \\
\text { GPAPQ }\end{array}$ \\
\hline$f b p B$ & $\begin{array}{c}16-21 \\
31-36 \\
78-83 \\
148-153 \\
156-161 \\
185-190 \\
210-215\end{array}$ & $\begin{array}{c}\text { IGTAAA } \\
\text { AGGAAT } \\
\text { LDGLRA } \\
\text { LSANRA } \\
\text { PTGSAA } \\
\text { AGSLSA } \\
\text { AGGYKA }\end{array}$ & $\begin{array}{c}8-11 \\
13-17 \\
26-29 \\
29-32 \\
33-36 \\
38-41 \\
44-48 \\
143-146 \\
152-155 \\
204-208 \\
214-217 \\
217-220 \\
224-228 \\
238-242 \\
245-249 \\
266-269\end{array}$ & $\begin{array}{c}\text { RAWG } \\
\text { RLMIG } \\
\text { GLVG } \\
\text { GLAG } \\
\text { GAAT } \\
\text { GAFS } \\
\text { GLPVE } \\
\text { ELPQ } \\
\text { RAVK } \\
\text { GLAMG } \\
\text { KAAD } \\
\text { DMWG } \\
\text { DPAWE } \\
\text { KLVAN } \\
\text { RLWVY } \\
\text { EFLE }\end{array}$ \\
\hline
\end{tabular}




\section{DISCUSSION}

In this study, the $f b p A$ and $f b p B$ genes of $M$. tuberculosis encoding the Ag85A and $\mathrm{Ag} 85 \mathrm{~B}$ proteins were successfully amplified using specific primers designed from the $M$. tuberculosis genome strain H37Rv. The results of amplification of the genes encoding Ag85A and Ag85B M. tuberculosis clinical isolates obtained specific bands with nucleotide sizes of $1071 \mathrm{bp}$ and $978 \mathrm{bp}$, respectively. Analysis of sequencing results of the $f b p A$ and $f b p B$ genes conducted by the ClaustalW program showed that the gene had a $99 \%$ similarity to the original sequence of the $M$. tuberculosis gene H37Rv. Sequencing of the $f b p A$ and $f b p B$ genes was done to confirm that there were no wrong gene sequences nor errors in the frame position of the gene to be inserted in the pET SUMO plasmids. The cloning process in this study was done by mixing fresh PCR products from the amplification results of the $f b p A$ and $f b p B$ genes into pET SUMO vectors based on the SUMO Protein Expression System Champion TM pET protocol, using Invitrogen kits. The digest using restriction enzyme of the insertion sequencing gene or plasmid in the ligation process were not done because pET SUMO vector has a $\mathrm{T}$ overhang sequence design. Taq polymerase from PCR products has a non-template dependent activity that adds a single deoxyadenosine (A) to end 3' The pET SUMO vector design used has an overhanging deoxythymidine $(\mathrm{T})$ at end 3 ' that can bind to a single deoxyadenosine (A) from PCR products. The growth of $E$. coli BL21 (DE3) competent cells that contain gene insertion was observed in LB Agar medium (containing kanamycin $50 \mu \mathrm{g} / \mathrm{mL}$ ). The colonies of E. coli BL21 (DE3) competent cells can be grown on media containing kanamycin because bacteria carry pET SUMO vectors that have a marker for the resistant gene to kanamycin. The PCR results of several colonies of E. coli BL21 (DE3) using specific primers were in accordance with the band size expected Amplification of deoxyribonucleic acid (DNA) plasmids carrying the $f b p A$ and $f b p B$ genes was also done using forward SUMO and T7 reverse primers to identify the insertion gene in the right frame. Results of some amplified colonies showed that $f b p A$ and $f b p B$ genes inserted in the pET SUMO were transformed to competent cells accurately. Alignment sequences using the ClustalW program indicate that the gene encoding Ag85A and Ag85B proteins insertion was in the right frame and there was no change in position or exchange between deoxyadenosine (A) start codon and deoxyadenosine (A) stop codon which binds to deoxythymidine (T) in the TA cloning site. SDS-PAGE of Ag85A and Ag85B recombinant proteins obtained from the sonication of E. coli BL21 (DE3) bacteria induced by $1 \mathrm{mM}$ IPTG showed that the bacteria were able to express $f b p A$ and $f b p B$ genes, with their molecular weights of $48-\mathrm{kDa}$ and $46-$ $\mathrm{kDa}$, respectively. The molecular weights of Ag85A and Ag85B proteins are 36$\mathrm{kDa}$ and 34-kDa, respectively. The addition of molecular weight in both types of protein is due to the addition of protein tags from pET SUMO plasmids of 12$\mathrm{kDa}$. The expression of recombinant proteins fused with SUMO (small ubiquitin related modifiers) shows a significant increase of proteins in the yield whose expression is very difficult to find in E. coli (Lee, 2008; Gopal and Kumar, 2013; Ceylan and Erdogan, 2017). Western blotting on PVDF paper using a monoclonal anti-histidine tag antibody was done to ensure the SDS-PAGE results were similar with the expected proteins. Monoclonal antibodies will bind with histidine sequences in taq SUMO of pET SUMO plasmids specifically. Western blotting results showed that the band was visualized after adding 1-step NBT/BCIP substrate solution according to SDS-PAGE results. Based on the analysis of the $f b p A$ and $f b p B$ gene sequences using the NCBI BLAST program results showed that all samples had $100 \%$ homology with several strains of $M$. tuberculosis and no similar sequencing was found with non-tuberculosis mycobacteria (NTM). The results of this homology indicate that the $f b p A$ and $f b p B$ genes of $M$. tuberculosis are highly conserved genes (Hugen 2014). The study conducted by Jiang et al. (2015) about single nucleotide polymorphism in Ag85 genes of Mycobacterium tuberculosis complex from samples of clinica isolates with several strains showed that only three of 180 samples had mutations with changes in amino acids, which were found in bases 47, 245, 312 for Ag85A proteins and in bases 44 and 140 for Ag85B proteins. The results of this study indicate that low amino acid changes occur in these proteins and show the highly conserved genes that encode both proteins (Jiang et al., 2015). We did analysis of specific T cell epitopes using GENETYX software ver. 8.0 and found seven specific $\mathrm{T}$ cell epitope positions based on the IAd Pattern position on both Ag85A and Ag85B proteins and twenty-three specific T cell epitopes based on the Rothbard/Taylor Pattern position for Ag85A proteins, whereas for Ag85B protein we found sixteen specific T cell epitopes based on the Rothbard/Taylor Pattern position. The prediction of T cells epitope carried out by D'Souza et al (2003) using EpiMer Program obtained five T cell epitopes for each Ag85A and Ag85B proteins. The position of $\mathrm{T}$ cell epitopes for Ag85A protein is present in the amino acid sequence 101-105, 121-134, 148-171, 198-207 and 270-280, whereas for Ag85B proteins it is present in positions 65-70, 101-105, 128-133, $146-154$ and 270-280. The study conducted by Zhang et al. (2016) found a different position of $\mathrm{T}$ cell epitopes on the Ag85B proteins. The results of their study revealed that the position of $\mathrm{T}$ cell epitopes was present in the amino acid sequence 45-58, 77-88, 98-107 and 191-206. In our study the results we obtained for the prediction of $\mathrm{T}$ cell epitopes were different with the studies conducted by D'Souza et al. (2015) and Zhang et al. (2016) who found five T cell epitopes on both $\mathrm{Ag} 85 \mathrm{~A}$ and $\mathrm{Ag} 85 \mathrm{~B}$ proteins. The difference in the number and position of $\mathrm{T}$ cell epitopes obtained by previous researchers with our research was probably caused by differences in the primers design used for amplification of the $f b p A$ and $f b p B$ genes, resulting in differences in the number of sequences of target genes obtained. This difference in results may also be due to the different programs used to predict T cells epitopes. The research conducted by D'Souza et al. (2015) predicted the $\mathrm{T}$ cell epitopes of Ag85 proteins using the EpiMer program, while Zhang et al. predicted $\mathrm{T}$ cell epitopes by software Proped, BIMAS and SYFPEITHI. Using GENETYX software, we predicted the Ag85A and Ag85B proteins T cell epitopes to understand the immune response to $M$. tuberculosis infection. Some studies state that the cellular immune system mediated by CD4+ T-cells and CD8+ T cells is very important for controlling latent and active TB (Dewi et al. 2018). Based on the T cell epitopes' prediction that we did, the results showed that the Ag85A and Ag85B proteins can be identified by $\mathrm{T}$ lymphocyte cells, which show that the protein has the potential as a subunit vaccine candidate and material for serodiagnostics for tuberculosis in the future (D'Souza et al. 2003)

\section{CONCLUSION}

In this study we succeeded in observing the cloning and expression of $f b p A$ and $f b p B$ genes of $M$. tuberculosis obtained from samples of clinical isolates in E. coli BL21 (DE3) competent cells, with molecular weights of 48-kDa and 46-kDa respectively. We discovered seven specific $\mathrm{T}$ cell epitope predictions based on IAd Pattern positions of Ag85A and Ag85B proteins, twenty-three specific T cell epitopes of Ag85A proteins and sixteen specific T cell epitope of Ag85B proteins predictions based on the Rothbard/Taylor Pattern positions.

Acknowledgments: The authors would like to thank the staff of One Health/Ecohealth Resource Center, University Gadjah Mada (OH/EH RC-UGM) This project was supported by PDUPT Ristek Dikti of Republic of Indonesia (NO: 177/UNI/DITLIT/DIT-LIT/TL/2018).

\section{REFERENCES}

Ceylan, H., Erdogan, O. (2017). Cloning, expression, and characterization of human brain acetylcholinesterase in Escherichia coli using a SUMO fusion tag Turkish Journal of Biology. 41: 77- 87. http://dx.doi.org/10.3906/biy-1602-83

Dewi, D.N.S.S., Soedarsono, Mertaniasih, N.M. (2018). T cell epitopes of the esxA full gene of Mycobacterium tuberculosis from sputum of MDR-TB patients. African Journal Infectious Disease. 12(2): 66-77. http://dx.doi.org/10.21010/ajid.vl2i2.10.

D'Souza, S., Rosseels, V., Romano, M., Tanghe, A., Denis, O., Jurion, F., Castiglione, N., Vanonckelen, A., Palfliet, K., Huygen, K. (2003). Mapping of murine Th1 helper T-Cell epitopes of mycolyl transferases Ag85A, Ag85B, and Ag85C from Mycobacterium tuberculosis. Infection and Immunity. 71(1): 483493. http://dx.doi.org/10.1128/IAI.71.1.483-493.2003.

Gopal, G.J., Kumar, A. (2013). Strategeis for the production of recombinant protein in Escherichia coli. Protein Journal. http://dx.doi.org/10.1007/s10930013-9502-5.

Gugino, G., Orlando, V., Cutrera, S., La Manna, M.P., Liberto, D.D., Vanini, V., Petruccioli, E., Dieli, F., Golletti, D., Caccamo, N. (2015). Granzyme A as a potential biomarker of Mycobacterium tuberculosis infection and disease. Immunologi Letters. 166:87-91. https://doi.org/10.1016/j.imlet.2015.05.019

Horwitz, M.A., Harth, G., Dillon, B.J., and Maslesa-Galic', S. (2000) Recombinant bacillus Calmette - Gue'rin (BCG) vaccines expressing the Mycobacterium tuberculosis $30 \mathrm{kDa}$ major secretory protein induce greater protective immunity against tuberculosis than conventional BCG vaccines in a highly susceptible animal model. Proceedings of the National Academy of Sciences of the United States of America. 97(25):13853-13858 http://dx.doi.org/10.1073/pnas.250480397.

Huygen, K. (2014). The immunodominant T-cell epitopes of the mycolyltransferases of the antigen 85 complex of $\mathrm{M}$. tuberculosis. Frontiers in Immunology. 321(5):1-11. http://dx.doi.org/10.3389/fimmu.2014.00321.

Indonesian Health Ministry. (2014). Profile of Indonesian Health 2018. Jakarta Indonesia.

Jiang, Y., Liu, H., Li, M., Li, G., Pang, H., Dou, X., Zhao, X., Wan, K. (2015) Single nucleotide polymorphism in Ag85 genes of Mycobacterium tuberculosis complex: analysis of 178 clinical isolates from China and 13 BCG strains. International Journal of Medical Sciences. 12(2):126-134. http://dx.doi.org/10.7150/ijms.9951

Kuo, C.J., Christopher, P., Ching, L., Bruce, L., Yung, F. (2013). Elastin, a novel extracellular matrix protein adhering to mycobacterial antigen 85 complex. The Journal of Biological Chemistry. $288 \quad$ (6): $3886-3896$. http://dx.doi.org/10.1074/jbc.M112.415679

Lee, C-D., Sun, H-C., Hu, S-M., Chiu, C-F., Homhuan, A., Liang, C-H., Leng, CH., Wang, T-F. (2008). An improved SUMO fusion protein system for effective production of native proteins. Protein Science. 17:1241-1248. : http://dx.doi.org/10.1110/ps.035188.108

Launois, P., Annie, D., Eliane, B., Pierre, C., Claire-Mich`ele, F., Jean-Paul, V.W., Kris, H. (2011). T Cell reactivity against mycolyl transferase antigen 85 of 
M. tuberculosis in HIV-TB coinfected subjects and in AIDS patients suffering from tuberculosis and non tuberculous mycobacterial infections. Clinic. and Dev. Immunol. 10:1155-1166. http://dx.doi.org/10.1155/2011/640309

Metcalfe, H.J., Steinbach, S., Jones, G.J., Connelley, T., Morrison, W.I.,

Vordermeier, M., Villarreal-Ramos, B. (2016). Protection associated with a TB vaccine is linked to increased frequency of $\mathrm{Ag} 85 \mathrm{~A}$-specific $\mathrm{CD}+\mathrm{T}$ cells but no increase in avidity for Ag85A. Vaccine. 34: 4520-4525 http://dx.doi.org/10.1016/j.vaccine.2016.07.055

Piubelli, L., Campa, M., Temporini, C., Binda, E., Mangione, F., Amicosante, M., Pollegioni, L. (2013). Optimizing Escherichia coli as a protein expression platform to produce Mycobacterium tuberculosis immunogenic proteins Microbial Cell Factories. 12:115. http://dx.doi.org/10.1186/1475-2859-12-115.

Rizzi, C., Bianco, M.V., Blanco, F.C., Soria, M., Gravisaco, M.J., Montenegro, V., Vagnoni, L., Buddle, B., Garbaccio, S., Delgado, F., Leal, K.S., Cataldi, A A., Dellagostin, O.A., Bigi, F. (2012). Vaccination with a BCG strain overexpressing Ag85B protects cattle against Mycobacterium bovis challenge PloS ONE. 7(12):e51396. http://dx.doi.org/10.1371/journal.pone.0051396

Wang, X., Chen, S., Xu, Y., Zheng, H., Xio, T., Chen, X., Huang, M., Zhang, H. Fang, X., Jiang, Y., et al. (2017). Identification and evaluation of the novel immunodominant antigen Rv2351c from Mycobacterium tuberculosis. Emerging Microbes \& Infections. 6:1-8. http://dx.doi.org/10.1038/emi.2017.34.

Wang, D., Jia, X., Yonghui, F., Ying, L., Solum, M., Fengping, S., Jin-Ichi, S., Chanlong, L. (2010). Liposomal oral DNA vaccine (mycobacterium DNA) elicits immune response. Vaccine Elsevier. 28(18): 3134-3142. http://dx.doi.org/10.1016/j.vaccine.2010.02.058.

World Health Organization. (2018). Global Tuberculosis Control: WHO Report 2018

World Health Organization. (2014). Global Tuberculosis Report 2014. WHO Report. World Health Organization Press, Geneva, Switzerland.

Yuk, J-M., and Jo, E-K. (2014). Host immune responses to mycobacterial antigens and their implications for the development of a vaccine to control tuberculosis. Clinical and Experimental Vaccine Research. 3(2): 155-167. http://dx.doi.org/10.7774/cevr.2014.3.2.155

Yuen, C.M., Weyenga, H.O., Kim, A.A. (2014). Comparison of trends in tuberculosis incidence among adults living with HIV and adults without HIV -
Kenya 1998-2012. Plos
One.
9:
e99880. http://dx.doi.org/10.1371/journal.pone.0099880

Zarif, R., Sankian, M., Gholubi, A., Farshadzadeh, Z., Soleimanpour, S., Youssefi, F., Varasteh, A.R. (2013). Cloning and expression of Mycobacterium tuberculosis major secreted protein antigen 85B (Ag85B) in Escherichia coli. $\begin{array}{lll}\text { Jundishapur Journal } & \text { Microbiology. } & \end{array}$ http://dx.doi.org/10.5812/jjm.4701

Zhang, F., Lu, X., Guo, N., Zhang, Y., Ji, P., Hu, J., Zhang, Z., Li, Z., Li, F., Ding, J. (2016). The prediction of T- and B-combined epitope of Ag85B antigen of Mycobacterium tuberculosis. International Journal Clinical and Experimental Medicine. 9(2):1408-1421.www.ijcem.com /ISSN:1940-5901/IJCEM0016951 